\title{
Journalism as a field of study in the US higher education system
}

\author{
K. Martsikhiv, N. Mukan \\ Lviv Polytechnic National University, Lviv, Ukraine \\ Corresponding author. E-mail: khrystyna.hrytsko@gmail.com
}

Paper received 23.06.19; Accepted for publication 11.07.19.

\begin{abstract}
https://doi.org/10.31174/SEND-PP2019-201VII81-05
\end{abstract}
\begin{abstract}
The article dwells upon the investigation of the current state of journalism as a field of study in the context of higher education system in the USA. The research presents a historiographic review of the development of journalism as a separate academic discipline and an independent field of study at US universities. The origins of journalism discipline and higher education establishments in the USA are analyzed. The scientific work reviews the official normative documents in the sphere of journalism in the USA. The profound analysis of instructional programs, dedicated to the professional training of journalists in the US has been carried out.

Keywords: field of study, discipline, professional training, journalism, instructional program.
\end{abstract}

Introduction. Processes of globalization that take place in the world influence social, cultural, political and economic spheres of the society and lead to transformational changes in the context of higher education system. It is important to note, that education is considered to be one of key factors of the society that impacts the economic country development and facilitates the formation of competent strategy, related with the professional training of specialists.

Journalism as a field of study plays an important role in the context of US higher education system and offers effective training programs. Organizations of international, national and European levels promote integrative processes in the sphere of journalism at US universities, elaborate standards and mechanisms that provide highquality professional journalistic training, improve the teaching methodology, and examine the issue of accreditation and international recognition of educational courses and programs. That is why, without any doubt, journalism and other correlated disciplines need active inclusion in the educational process and upbringing of growing generation. It is also important to highlight the fact that the US experience of journalistic professional training can be optimized in the Ukrainian educational process.

Brief overview of publication on the topic. The problems of theoretical and practical aspects of journalists' professional training are of great importance, namely: methods and forms of training for media professionals, analyzed by Weber, Beret, Bradford, Willnat \& Weaver, Galin, Greenberg, Goodman, Zelizer, content of journalists' professional training (Golovchenko, Ojalvo, Smith, Hobbs), forms of educational activities and the use of innovative technologies in journalists' training (Anderson, Gabor, Gavrilova, Carlson, Konovalchuk, Rizun, Smelkovova, Self, Chemeris); public-research training for media professionalists (Brit, Kalinina, Saltmarsh \& Zlotkovsky).

Over the past decades comparative-pedagogical studies have been a matter of scientific and practical concern of Bidyuk, Brazhnik, Wulson, Istomina, Mukan \& Shiyka, Lokshina, Nichalko, Sbrueva, Sysoeva, Tsura. Comparative-pedagogical researches of US higher professional education were carried out by Ukrainian researchers Bratko, Vitvitska, Diachenko, Dupak, Lutsenko \& Polivana, Nichkalo, Stoika, Tarasova, Shapran.

However, the analysis of scientific literature shows that in Ukrainian educational system very few studies have investigated the problem of journalism training in the USA in terms of higher modern education in the $21^{\text {st }}$ century. This led to the choice of the topic of our scientific research.

The aim of the study is to analyze features of the formation, development and current state of journalism as field of study in American system of higher education, the role of journalism in American society and Classification of Instructional Programs in the USA, dedicated to the study of journalism.

Methods and materials. In our scientific work we have used various theoretical and applied research methods. The comparative and historical methods have been applied to investigate different aspects of the origin and development of journalism as a field of study and academic major. Methods of deduction and induction have been used in order to generalize theoretical material of the problem; for the study of informational resources and processes logical methods have been applied. We have also used analysis and synthesis to study theoretical materials, program documents of American universities, official documents, norms and standards that regulate higher education in the USA. To gather pedagogical information applied methods have been used, namely dialogues and conversations with the heads of department at US universities.

Results and discussion. The United States is considered to be one of the leading countries in training journalists. But it is important to note, that there are factors that prevent it from achieving a unified national system, namely, a significant gap between states leads to the isolation of media education, especially when each state has its own authority. The lack of exchange experiences and ideas among state journalism instructors leads to the emergence of various private councils and agencies that offer their own proposals for journalism education and educational programs. Another factor is that the United States, as a multicultural country, faces difficulties in reaching a common agreement on issues related to media education [4].

However, in spite of these obstacles, journalism education in the United States is developing and improving. At the beginning of the XX century much attention was paid to discussion of the educational value of films. During this period, a model was established that focused on acquiring practical skills in the media, but there were also attempts to introduce theoretical disciplines into the edu- 
cational process. Students were forced to work eight hours in the typography and five more hours in the classrooms to study the necessary disciplines: grammar, spelling, philosophy, natural sciences and foreign languages. At that time, journalism was considered as an applied discipline, which had to be mastered through practical work in typographies [3].

It is necessary to outline, that in 60-80 years of XX century in the United States, most journalism schools have been renamed as media colleges, and journalistic disciplines have become a new subject of research. In comparison with the previous period, during which considerable attention was paid to the practical training of students, namely, their ability to collect information, to organize it, to carry out technological output, then this stage is characterized as the studying of humanitarian disciplines [19].

The beginning of the XXI century is thought to be the time of high achievements of American pedagogy. With the help of Internet sites, publications, conferences, it has a significant influence on the development of media education in other countries. During this time several media associations were developed in the USA: the Center for Media Education in Washington, the Center for Media Literacy Center in Los Angeles, The Educational Video Center in New York, The Strategies for Media Literacy Association and the National Alliance for Media Arts and Culture in San -Francisco. At that time, the US president signed the Goals 2000: Educate America Act, which envisages so-called content standards with 9 specialties [16].

As a result of successful development of journalism as the popularized field of study, the necessity appeared to set standards to regulate professional training in this sphere. During the years 2007-2009, the Association of College and Research Libraries collaborated with a variety of educational institutions to introduce information literacy standards for would be journalists in the United States. Information literacy is characterized by the ability to choose the necessary material, evaluate and effectively use it, post in a particular section of news, etc. Namely, the application of informational professional literacy by journalists promotes high-quality reporting, provides future professionals with work in a competitive market and improves the level of public discourse [1].

According to the analysis of the source base, it is concluded that the optimization of the educational process of future professionals in the field of journalism is relevant for the US higher education system. This is evidenced by documents from American, Ukrainian and international organizations. It should be pointed out that institutions, professional associations, public and governmental organizations make efforts to improve the content of educational and professional journalism programs; to intensify innovative learning methods; organize international mobility of journalist students; establish common professional standards; quality assurance and monitoring of education, etc.

It is significant to highlight that the study of Bachelor's degree in humanities in the field of journalism is based on a detailed analysis of the concepts, theory and trends of journalism development.

At the present stage of the development, journalism education is characterized by the formation of the national security concept of a convergent society, which differs significantly from the concept of the national security of the industrial society. According to the opinion of the scientist S. Klepko, the concepts that are active in American education are valuable for Ukraine: the concept of an active school, charter schools, civic education [8, p.242].

By investigating the professional journalists' training at US universities at the beginning of the $21^{\text {st }}$

century, we can distinguish various trends. An effective system of higher education in the United States is

the tendency to improve and expand «short and professional education»: journalist students gain a solid

education for three years of study and as a result they can become competitive in the labor market. Examples of such programs can be found at the University of North Carolina, Manchester College, Ball State University, American University in Washington, Hartwick College and other institutions [13].

It is outlined that the tendency of diversification is viewed as a positive phenomenon for the structure of higher education in the United States and occurs in parallel with the diversification of degrees and qualifications that higher institutions offer. In order to meet the requirements of the labor market in the United States, new programs have been introduced for Bachelor's degree in journalism, a number of undergraduate courses have been developed, according to which students can obtain a degree of a dual specialization.

It should be noted that the US higher media education system is characterized by «open» admission of future journalists. The level of rights for all citizens to choose an educational institution according to needs and interests is a manifestation of democratic trends in journalism education in the United States [18].

Equally important trend in the development of journalism education is the transition from group to individual learning: trainings'organisation, practices under the direction of a teacher, tutor lessons, works in small groups, etc. These training conditions help to optimize the educational process of journalists in taking decisions in various extreme situations [18].

The analysis of journalism education in the United States suggests the increasing tendency of internationalization, which is due to internal and external causes. As it was discovered, education is the important component of the country's economic development that is why future journalism professionals have to meet the needs of the labor market and ensure the country's competitiveness.

It is doubtless, that the USA created a favorable basis for the professional development of future journalism specialists. Its higher education system is viewed as effective due to well-organized structure and positive student's outcomes. The Normative document as the Classification of Instructional Programs helps to regulate the educational process in the country.

Classification of Instructional Programs has been elaborated by Statistics Canada and National Center for Education Statistics in the USA. This classification consists of three-stage hierarchical system. The first section presents the classification, in which educational programs are combined according to specific broad fields of study, which are marked with two-digit codes. These broad fields of study are divided into specific fields of study, 
which are marked with four-digit codes. These fields of study, in its turn, are divided into specific majors, according to which the separate instructional programs are classified. Every instructional program is marked with sixdigit code. Thus, Journalism as a field of study has a fourdigit code '09.01', where the number '09' means belonging to a wider field of Humanitarian Sciences, and digits after the dot indicate the serial number in the classification.

According to the Classification of Instructional Programs, specialization 09.01 «Communication and Media Studies», 09.04 «Journalism», 09.07 «Radio, Television and Digital Communication», 09.09 «Public Relations, Advertising, and Applied Communication», 09.10 «Publishing» is a part of branch of the knowledge 9 «Communication, Journalism and related programs» [5].

Carrying out the analysis of journalism education in the USA main theoretical approaches were outlined. The semiotic theory is related to the fact that media workers often conceal the true meaning of texts that is why the main aim of media workers is to help the audience to understand the information correctly [7]. According to the cultural theory, Mass Media do not impose, but offer their interpretation of reality. The audience do not only perceive information, but introduce in it different content. As a result, the main task of media education is to enrich and improve the knowledge of the audience in the perception of media texts. The aesthetic theory of journalism education consists in the students' correct understanding of basic laws and language of media texts, as well as contributing to the development of artistic information perception and the ability to skillfully analyze it.

The Marxist theory of media education emphasizes on the fact that mass media workers are able to manipulate public opinion in their favor. For such an impact, a simple target is a children's audience. That is why journalist student have to learn how to deliver information in a right way.

The theory of journalism education as a means of forming critical thinking can be viewed as a concept according to which media are considered as the «fourth power» and promote the models of behavior and values among different population. As a result, the aim of media education is to protect students from the manipulative media impact [7].

The main task of the «injection theory» is to reduce the negative influence mainly on the children and youth audience [11]. The aim of "practical theory» is to teach student journalists to use media equipment properly and develop practical skills for creating media products [7].

As a result of research, it was discovered that the development of educational programs for bachelors of the humanities in the field of journalism at US universities is focused on the following principles: normative individualism, authoritarianism, freedom of public affairs, libertarian, empiricism and social responsibility.

According to the principle of «normative individualism», the aim of the professional journalists' training

is the formation of individual moral qualities of media professionals; satisfaction of the economic and social needs of the society, namely actions following the laws of the country, but not their own interests and preferences. It is necessary to note that a journalism specialist is viewed as an «individual» who has to develop and maintain a relationship with the public [9, p.1790-1793].

Within the framework of the concept of «authoritarianism», a media specialist must obey the public, develop and support government policies, act for the sake of the state, and not criticize and destroy stereotypes of power [17].

It is also significant to highlight that the freedom expression plays a vital role in the training of journalists at US universities, providing students with an opportunity to show their independence and autonomy, and express their opinions without fear of government control and censorship [6].

The foundations of empiricism reasonably is thought to be dominant one in the professional journalist training at US universities and significantly influenced the «gatekeeper model», the "agenda setting», and the theory of «value news» According to the «Information Access Controller» model, journalism students learn how to «open the gate» which means how to start the report, as well as to complete.

According to the «agenda setting» model, would be specialists must gain skills how to correctly report information, giving the priority to the most important data. Due to the concept of the «framework» journalists should pay attention only to main aspects of the report and neglect the secondary ones.

The «value news» theory consists in that future journalism specialists need to learn how to create news following quality indicators of news: frequency, threshold, transparency, familiarity, predictability, etc. Consequently, we can sum up that empirical foundations are the basis for the professional training of journalists, since they are based on the following aspects: professional positions of media workers; professionalization and socialization of media companies; structure and working conditions for future professionals [15].

The theory of «social responsibility» has a big influence on the process of professional journalist training. According to this theory, future media specialists do not have to interfere in the secret and important affairs of the state, but instead, be in charge of serving the political system, providing information on public affairs of the country; protection of individual rights; controlling the governmental actions; servicing the economic system by establishing links between sellers and buyers of the media product; provision of entertainment activities; support for their own financial self-sufficiency, without being subjected to pressure from third parties [2].

The professional training of bachelors of the humanities in the field of journalism at US universities is the concept of active learning, which is based on the theory of constructivism. According to a constructivist paradigm, students gain high learning outcomes when they actively participate in the learning process; independently construct their knowledge while doing the tasks and taking autonomous decisions. As Scholl explains, [14], constructivism contributes to the effective teaching of journalism students, development of their professional skills in transforming and reproducing real facts. Active learning is a teaching method, which is concentrated on active involvement of students in the educational process; self- 
analysis, comparison and critical evaluation of information [12]; personal responsibility for the learning process [10].

From the above information, we can sum up that such concepts, theories and trends in the development of journalism education in the United States are due to the globalization processes taking place in the country.

Conclusions. To conclude, we can state that the results of our research have proven that the USA have a leading and successful tradition of professional journalistic training due to well-developed higher education system, requirements and standards. American universities are viewed as highly rated among the educational establish- ments that offer programs in journalism. It is also necessary to outline that the reputation of American professional training in journalism is due to the specific instructional programs that are oriented on practical study and professional activity. It is also noted, that the professional journalistic training in the USA is considered to be a source for further research. The scientific work, in perspective, can be an object for more detailed content analysis of professional training in the sphere of journalism in the USA. The future research will be carried out to explore academic achievements of students, methods and forms of studying, applied in professional journalistic training.

\section{REFERENCES}

1. Associate of college \&research libraries (2012). Retrieved from:

http://www.ala.org/acrl/sites/ala.org.acrl/files/content/standar ds/ils_recomm.pdf

2. Belair-Gagnon, V. (2018). Sociology of news. Retrieved from: https://www.academia.edu/36969332/Sociology_of_News_W ork_proofs_

3. Bykov, A. (2015). Formation of ideas about freedom of speech: experience journalism education in the United States. Problemy obrazovanyia, nauky y kultury [Problems of education, science and culture], 3 (141), 37-45

4. Chen, G.M. (2007).Media (Literacy) Education in the United States, Is. 3, 87-103.

5. Classification of Instructional Programs (2010). Available at: https://nces.ed.gov/IPEDS/CIPCODE/cipdetail.aspx? $\mathrm{y}=55 \& \mathrm{c}$ ipid $=88043$

6. Franlkin, B. (2005). Concepts. M. Hamer, Hanna M. Hanna, M. Kinsey (Eds). Key concepts in journalism (pp.1-23). London: Sage publications.

7. Kirilova, N. (2012). Medialogiya kak sintez nauk [Mediology as a synthesis of sciences], 71-83

8. Klepko, S. (2006). Filosofiia osvity v yevropeiskomu konteksti [Philosophy of Education in a European Context], Poltava: POIPPO

9. McPherson, K.S. (1997). Individualism. Eatwell, J., Milgate, M., P. Newman. A dictionary of Economics (pp.1790-1793). New Palgrave

10. Mostrom, A. \& Blumberg P. (2012). Does learning-centered teaching promote grade improvement? Innovative Higher Education, Is. 37 (5), 397- 405

11. Oblasova O. \& Stepanchko Yu. (2012). Osoblyvosti mediaosvity v Ukraini na suchasnomu etapi [Features of media education in Ukraine at the present stage]. Retrieved from: http://www-

philolo-

gy.univer.kharkov.ua/nauka/e_books/visnyk_1027/content/ob lasova_stepanchenko.pdf

12. Prince, M. (2004). Does active learning work? A review of the research. Journal of Engineering education, Is. 93 (3), 223-231

13. Savchenko, N. (2015). Osnovni idei ta napriamky rozvytku vyshchoi osvity u sviti [Key Ideas and Directions for the Development of Higher Education in the], Is.135, 23-27

14. Scholl, A. (2011). How Constructivist Philosophy Enriches Journalism Research. Review of «The Creation of Reality: A Constructivist Epistemology of Journalism and Journalism Education». Constructivist Foundations, Is. 6 (2), 275-277

15. Schudson, M. (2003). The sociology of news. K. WahlJorgensen \& Thomas Hanitzsch (Eds). Handbook of journalism (pp. 88-94), New York: Norton

16. Shesterkyna, L. (2012). Zhurnalistskoe obrazovaniye v usloviyakh konvergentsii [Journalism Education in Convergence Media], 98-102.

17. Sterling, C. H. (2009). Encyclopedia of Journalism (p.1393).Sage publications

18. Stoika, O. (2017). Vyshcha osvita SShA ta Ukrainy: vidminni ta spilni rysy [Higher education in the United States and Ukraine: distinctive and common features], Is. 1(40), 281-282 19. Vynychenko, V. (2010). US Journalism Education: From Journalism to mass communications, 1 (10), 100-112 